\title{
İlköğretim Fen Bilgisi Dersi 7. Sınıf Uzay Bilmecesi Ünitesinin Yaratıcı Drama Yöntemi İle Ele Alınması
}

\section{Berna SAVAŞÇ I ${ }^{1}$}

\author{
PInar ÖZDEMİR ŞIMŞEK²
}

\begin{abstract}
$\ddot{O}_{z e t}$
Bilginin edinilmesinin çok da zor olmadı̆̆ günümüzde bilgiyi değişen durumlara uyarlayarak kullanmak, yeni fikirler yaratmak ve yaratıcıll̆̆̆ desteklemek için klasik yöntemlerden farklı yöntem ve teknikler kullanmak gerekir. Ĕgitimde yaratıcı drama ögrencinin kafasında tam olarak anlamlandıramadĭ̆ı gezegen, uzay, astronot, kuyruklu yıldı, meteor gibi kavramları doğaçlama ve canlandırma tekniklerinden faydalanarak onlar hakkında yaşantılar oluşturmasına, bilgiyi kalıcı hâle getirmesine ve kavram kargaşasına düşmeden bu kavramları öğrenmesine olanak sağlamaktadır. Bu çalışmanın amacı ilköğretim 7. sinıf ögrencilerinin İlköğretim Fen ve Teknoloji Öğretim Programı'nda bulunan "Uzay Bilmecesi” ünitesinde yer alan gök cisimlerinin (yıldız, kuyruklu yıldız, takımyıldızı, meteor, gezegen, güneş) özelliklerini ve birbirleriyle olan uyumlarını yaratıcı drama yöntemi ile yaşantılar oluşturarak programda yer alan hedef kazanımlara ulaşmalarını sağlamaktır. Bu çalışmanın örneklemini 2010-2011 Ĕ̈itim Öğretim Yll Bahar Döneminde Konuklu İlköğretim Okulu 7/A şubesine devam eden 13-15 yaş arası, çalışmaya gönüllü olarak katılan, yaratıcı drama geçmişi bulunmayan 6 klz 8 erkek toplam 14 ögrenci oluşturmaktadır. 1-13 Mart tarihleri arasında her gün birer saat olmak üzere 12 saatlik atölye çalışmaları belirlenen grupla yapılmıştır. Hazırlanan 12 ders planının(Ek-1) 1 tanesi ekte örnek olarak sunulmuştur. Çalışma süreci ve sonucu açısında bilgi sahibi olmak üzere ögrencilere uzay bilmecesi ünitesine ait hedef kazanımlara ait başarı testi ön test - son test olarak uygulanmış, öğretmenin gözlemlerinden faydalanılmış ve ögrencilerden çalışma süresince günlük tutmaları istenmiştir. Veri toplama araçlarından elde edilen bulgulara bakılarak öğrencilerin programda hedeflenen kazanımlara ulaştıkları, ünite içinde geçen kavramlar hakkında yaratıcı drama yöntemi ile bilgi sahibi oldukları söylenebilir.
\end{abstract}

Anahtar sözcükler: Uzay, yaratıcı drama, yıldız, kuyruklu yıldız, takımylldızı, meteor, gezegen, astronot

\section{Unit of the 7th Grade Elementary School Science Lesson "Space Enigma" to be dealt with Creative Drama Method}

\begin{abstract}
Today, it is not too difficult to adopt the information however there is a need to benefit from different methods and techniques to support creativity different from the classical methods to use the information in changing circumstances and to create new ideas and methods. Creative drama in education helps students to learn concepts which they cannot make sense of such as planets, space, astronaut, comet, meteor through improvisation and animation techniques utilizing experiences to provide permanent learning without the confusion of concepts. The purpose of this study is to achieve the goals of the unit: "Space Enigma" in the 7th grade curriculum which covers properties and intercompatibility of the space bodies (stars, comets, constellations, meteors, planets, the sun) using the creative drama method to help 7 th grade students to have experiences and make a clear sense of these bodies. The sample of this study consists of 6 girls and 8 boys at total 14 students who are attending to 7/A classroom at Konuklu Elementary School in the spring term of the 2010-2011 academic year, do not have a creative drama background. From March 1 to 13 an hour a day at total 12 hours of workshops has been carried out. One of the 12 lesson plans prepared is presented as an example (annex 1). To have a clear idea of the process and the
\end{abstract}

1 Öğretmen, Milli Eğitim Bakanlığı, bernasavasci@mynet.com.tr

2 Yrd. Doç. Dr. Hacettepe Üniversitesi, pozdem@hacettepe.edu.tr 
results pre-tests and post-tests about "Space Enigma" have been applied, teachers'observations are taken into consideration and students have been asked to keep dairies during the process. According to the results obtained from data collection tools, it can be claimed that students have achieved the goals of the curriculum and they have a clear idea of the concepts in this unit with the help of the creative drama.

Keywords: Space, creative drama, comet, constellation, stars, meteors, planets, astronauts

\section{Giriş}

21. yüzyıl bireyin kendini ve çevresini tanıyarak yapabileceklerinin farkında olmasını, yeni süreçlere uyum sağlamasını, problem durumlarında yeni bakış açıları geliştirerek çözümler üretmesini gerektiren bir dönemdir. Eğitim bireyin süreçte gelişmesine, değişmesine ve yeni durumlara uyum sağlamasına katkıda bulunur. Bireyin değişen şartlara uyum sağlama gereği okullarda verilen eğitim anlayışını da değiştirmiştir. Artık merak eden, araştıran, sorgulayan, farklı performanslar gösteren, proje üreten öğrenciler yetiştirilmek istenmektedir. Hayat boyu öğrenme düşüncesi önem kazanmıştır. Bu düşünce ile bireyler edindikleri bilgileri günlük yaşamlarındaki problem durumlarına çözüm olarak kullanacaktır. Bu da bilginin işe yaramasını ve öğrenmenin süreklik kazanmasını sağlayacaktır. Günlük yaşamda çözüm sağlayan bilgi anlamlı olacağından kalıcı hale gelecektir. Etkili bir fen eğitiminin gerçekleşmesi ise ancak anlamlı ve kalıcı bir öğrenmeyle sağlanabilir (Yürük ve Çakır, 2000). Öğrenme ile ilgili yapılan çalışmalar, bireylerde var olan ön fikirlerin, anlamlı öğrenmede oldukça etkili olduğunu ortaya koymaktadır (Akdeniz vd., 2001). Çocuklar, dünyayı kendi deneyimleri ile tanıyarak zihinlerinde gerçek bilimsel düşüncelerden farklı bir düşünce süreci oluştururlar. Bu düşünce sürecinde oluşan ve bilimsel düşüncelerle çelişen kavramlara "kavram yanılgıları" adı verilir (Büyükkasap vd., 1998). Fen öğretiminde öğrencilerin kavramları doğru öğrenmeleri ve kavramlar arası anlamlı ilişkiler kurmaları oldukça önemlidir. Çünkü ilköğretim yıllarında öğrencilerin zihinlerinde oluşan yanlış anlamalar, orta öğretim ve yüksek öğretim yıllarında ciddi problemler oluşturmaktadır (URL-2, 2005). İlköğretim, çocuğun çevresini anlamaya yönelik bilgi edinmesini sağlama ve bir düşünce sistemi geliştirmesine yardım etme gibi fonksiyonları içerir (Kaptan, 1998).

McDermott (2003), fen bilgisi derslerinin en temel amacını, bilimsel anlayışlar çerçevesinde öğrencilerin, temel kavramları anlamalarını sağlamak ve kavram yanılgılarını ortadan kaldırmak olarak belirtmiştir. $\mathrm{Bu}$ çalışmanın öğrencilerin ilk kez karşılaştıkları bazı kavramları kavram yanılgısına düşmeden öğrenmesine ve yaşantılar sonucu bilgiyi daha kolay yapılandırmasına olanak sağladığı düşünülmektedir. Kavram yanılgıları, bilimsel düşünme ve problem çözme gibi konularda, hatalı yargılara neden olmakta ve bu yanılgılar giderilmezse öğrenciler sürekli bilimsel hatalara düşmektedirler (Gümüş vd., 2005). Geleneksel yöntemlerle yürütülen derslerin öğrencilerdeki kavram yanılgılarının giderilmesinde ve anlamlı öğrenmenin sağlanmasında çok fazla etkili olmadığı ve yaratıcılığı artırmadığı bilinmektedir (Uzuntiryaki vd., 2001; Tezci ve Gürol, 2005). Fen öğretiminde anlamlı öğrenme sağlamak için, önce kavram yanılgılarının tespiti, sonra tespit edilen yanılgıları giderecek çağdaş yöntemlerin kullanılması gerekmektedir (Özmen vd., 2001; Uzuntiryaki vd., 2001).

Fen ve Teknoloji dersi; anlamayı, anladıklarını yorumlamayı, öğrendiği formül ve kavramları ilişkilendirerek uygulamayı gerektiren bir derstir. Bu yüzden öğrencilerin, öğretmenlerin derste uyguladıkları öğretimi anlama zorluğu çektiği ve başarısızlığa uğradığ 1 derslerden biridir. Bu sebeple öğrencilerin kavram yanılgısına düşmeden, yaşantılar yoluyla, öğretilenleri olabildiğince somutlaştırarak öğrenmelerinde yaratıcı drama yöntemi iyi bir alternatiftir. Fen ve teknoloji ders kitaplarının içeriği incelendiğinde bu kitaplarda bilginin doğrudan sunulduğu ve bu kitapları kullanan öğretmenlerin de fen ve teknoloji bilgilerini bir son ürün olarak ele alarak, sınıf ortamında sadece bilimsel bilgiyi aktarıp, bilimsel ilkelerin ve kavramların gelişim süreçlerini göz ardı etmekte olduğu görülmektedir( Anderson,1987).

Fen, fiziksel ve biyolojik dünyayı tanımlamaya ve açıklamaya çalışan dinamik ve beşeri bir faaliyettir. Fen, sadece dünya hakkındaki gerçeklerin bir toplamı değil, aynı zamanda deneysel ölçütleri, mantıksal düşünmeyi ve sürekli sorgulamayı temel alan bir araştırma ve düşünme yoludur. Bilimsel metotlar; gözlem yapma, hipotez 
kurma, test etme, bilgi toplama, verileri toplama, verileri yorumlama ve bulguları sunma süreçlerini içerir. Hayal gücü, yaratıcılık, yeni düşüncelere açık olma, zihinsel dürüstlük ve sorgulama bilimsel faaliyetlerde oldukça önemlidir. Tüm bu verilerle fen öğretimi ve yaratıcı dramanın birçok alanda uyumlu olduğu görülmektedir.

Yurtdışında bu konu hakkında yapılan çalışmalardan, Boujaoude, Sowwan ve Abd-El-Khalick'in (2005) yaratıcı dramanın fen eğitiminde kullanımı üzerine on dört lise öğrencisi ile yaptıkları çalışma örnek verilebilir. On dört lise öğrencisi ile bazı bilim insanlarının yaşam öyküleri üzerinde çalışılmış ve yaratıcı drama yöntemi temel yöntem olarak ele alınarak öğrencilere bilim insanlarının yaşam öyküleri sunulup bu yöntemin öğrencilerin bilimin doğasını kavramalarına yardımcı olduğu sonucuna varılmıştır.

Kavram yanılgıları ile ilgili literatür ve dramanın yukarıda sayılan özellikleri göz önünde alındığında, yaratıcı drama yönteminin fen bilimlerindeki soyut kavramların somutlaştırılarak, yanılgıların giderilmesinde ve motivasyonun sağlanmasında etkili olacağına inanılmaktadır. Dramanın soyut kavramları somutlaştırma, başarıyı artırma, motivasyonu sağlama gibi etkilerinin bulunduğu bilinmektedir (Kamen, 1992; Erhan,2000; Pantidos vd., 2001; Sağırl1, 2001).

Fen bilgisi öğretimi bireylerin yaşantılarında önemli bir yer tutmakta, insanları zihinsel ve yaratıcılık yönünden geliştirmekte ve iyi bir eğitimin de temeli olarak kabul edilmektedir (İşman vd., 2005). Fen öğretiminde, hedeflenen düzeyde başarı elde edilebilmesi için, derslerin uygulamaya dayalı olarak yürütülmesi gerekmektedir. Ancak okullarımızın fiziki imkân yetersizlikleri, öğretmenlerin konuları yetiştirme kaygısı ya da birçok deneyin çok zaman alabileceği düşüncesiyle dersler uygulamaya dayalı yürütülememektedir (Kurt, 2002; Hardal, 2002; Güneş, 2005). Yeni fen eğitimi yaklaşımlarında, alternatif yöntemlerden biri olarak görülen eğitici drama yöntemiyle, eğlenceli bir ortamda öğretim gerçekleşmekte, öğrenciler hem dersi sevmekte hem de oyun içerisinde aktarılan konuyu anlamaktadırlar (Sağırlı, 2001; Albayrak ve Akdemir, 2002).

Etkili öğrenme sürecinde gerçek durumlardan faydalanmak esastır. Ancak gerçek durumların oluşturulması ve her türlü araç-gerecin sağlanması her zaman mümkün olmayabilir. Bu gibi durumlarda, uygulanan drama yöntemi ile hem anlaşılmayan konuların anlaşılması sağlanmış hem de öğretim faaliyetleri çeşitlendirilerek ders ilgi çekici hale getirilmiş olur (Tanrıseven, 2000).

Fen bilimleri, matematik, sosyal bilgiler ve daha birçok alanda, drama ile geliştirilen etkinliklerin motivasyonu sağladığı, başarıyı artırdığı, soyut kavramları somutlaştırarak kavramsallaştırmayı ve kalıcılığı sağladığı ile ilgili pek çok çalışma bulunmaktadır (Aral vd., 1981; Kamen, 1992; Labow ve Sewell, 1993; Üstündağ, 1997 ; Pantidos vd., 2001).

Bu çalışmalar doğrultusunda İlköğretim 7. sınıf Fen ve Teknoloji dersi kapsamındaki "Uzay Bilmecesi" ünitesinin yaratıcı drama yöntemi kullanılarak işlenmesinin öğrencilerin etkinliklere motivasyonunu sağlayacağı, başarıyı arttıracağı, soyut kavramları somutlaştırarak kavram kargaşasına düşmeden kavramsallaşmayı ve kalıcılığ1 sağlayacağı düşünülmektedir.

\section{Çalışmanın Önemi}

Yapılan araştırmalarda alan yazın içinde yaratıcı drama ile işlenen ilköğretim 7. sınıf Fen ve Teknoloji Dersi Öğretim Programında yer alan "Uzay Bilmecesi” ünitesine ait bir çalışmaya rastlanmamıştır. Bunun yanı sıra çalışma grubunun eğitim gördüğü ilköğretim okulundaki öğrenciler ile yapılan yapılandırılmamış görüşmelerde öğrenciler yaratıcı drama ile daha önce tanışmadıklarını belirtmişlerdir. Bu yöntemle ders işlemek konusunda öğrencilerde merak uyandığ 1 ve ünitedeki bilgilere ilgilerinin arttığı öğrenciler tarafından dile getirilmiştir. Ayrıca bu çalışmanın yaratıcı darama liderliği proje aşamasında bulunan ve fen bilgisi öğretim müfredatını konu alacak lider adaylarına bir örnek oluşturacağı düşünülmektedir.

Çalışma grubunun yaratıcı drama geçmişinin bulunmadığ 1 göz önüne alındığında bu çalışma sonrasında öğrencilerin bu yöntem sayesinde ders konularına bakış açılarının değişeceği, çalışmanın öğrenmeyi zevkli ve 
farklı kılacağı düşünülmektedir. Bu sonuçla birlikte öğrencilerin yaşantılar yoluyla, kavram karmaşasına düşmeden öğrenmeyi öğrenecekleri sonucuna varılmıştır.

Çalışma konusu, öğrencilerin günlük yaşamda konu ile ilgili yaşantılar geliştirmesinin zor olduğu, soyut kavramları içerdiği ve öğrencilerin kavram karmaşasına düşebilecekleri bir konu olduğundan yaratıcı dramanın yaşantılar yoluyla, soyut kavramları somutlaştırmayı ve kavramsallaşmayı sağlayacağı öngörülmüştür. Yaratıcı dramada sıkça kullanılan rol oynama, doğaçlama, liderin role girmesi, rol içinde yazma tekniklerinin tüm sayılan amaçlara hizmet edeceği düşünülmektedir.

\section{Çalışmanın Amacı}

Bu çalışmanın amacı ilköğretim 7. sınıf Fen ve Teknoloji Dersi Uzay Bilmecesi ünitesinde yer alan gök cisimlerinin (yıldız, kuyruklu yıldız, takımyıldızı, meteor, gezegen ve güneşin) özelliklerini ve birbirleriyle olan uyumlarını yaratıcı drama yöntemi ile yaşantılar oluşturarak, kavram yanılgısına düşmeden, somutlaştırarak ilköğretim 7. sınıf öğrencilerinin öğretim programında yer alan; gök cisimlerini tanır, özelliklerini bilir, birbirleriyle uyumlarını fark eder hedef kazanımlara ulaşmasını sağlamaktır. Aynı zamanda bireyin kendini, yaşadığı gezegeni ve gezegeninin içinde bulunduğu galaksiyi tanımasına ve anlamasına yardımcı olmaktır. Katılımcıların drama geçmişi bulunmadığı için ilk iki oturum öğrencilerin birbirlerini tanımaları ve yaratıcı drama süreci hakkında bilgi sahibi olmaları için planlanmıştır.

\section{Yöntem}

\section{Araştırma Modeli}

$\mathrm{Bu}$ araştırmanın amacı yaratıcı drama yöntemi uygulamasının 7. sınıf öğrencilerinin başarılarına etkisini incelemektir. Bu amaca bağlı olarak araştırmada nitel ve nicel yöntemler bir arada kullanılmıştır. Araştırmanın deseni öntest sontest tek grup deneysel modeldir. Çalışmanın nicel boyutunda konu ile ilgili başarı testi öntest ve sontest olarak uygulanmış, nitel boyutunda ise gözlem ve doküman analizi ile sonuçlar desteklenmiştir.

\section{2. Örneklem}

Bu çalışmanın örneklemini Şanlıurfa Merkez Konuklu İlköğretim Okulu 2010-2011 eğitim öğretim yılı 7A sınıfı öğrencileri oluşturmaktadır. Katılımcı sayısı 6 kız 8 erkek olmak üzere 14 kişidir. Öğrencilerin yaş aralığı 13-15'tir. Birey, çocukluğundan yaşl1lığına kadar gelişen yaşam çizgisi üzerinde birbirinden farklı gelişim dönemlerinden geçer ve bu dönemler içerisinde birbiriyle aynı olmayan fizyolojik ve psikolojik bazı özellikler gösterir. Gelişim periyotlarının -başlangıç ve bitiş anlamında- kesin olarak yaş sınırlamasını yapmak oldukça güçtür ancak bu yaş aralığının ergenlik dönemi olarak adlandırılan dönemi içine aldığı bilinmektedir. Bu yaş aralığ dikkate alındığında aile dışında sosyalleşmenin başladığı, karşı cinse ilginin arttığı gözlenmektedir. Yine bu yaş aralığında bulunun kişilerin bilişsel beceriler açısından soyut işlemler döneminde olduğu söylenebilir (Arı, Üre, Yılmaz ;1998). Kendini ve çevresini tanıma yeniden anlamlandırma, yaratıcılık gibi özelliklerin ön plana çıktığı bu dönemde yaratıcı drama yöntemi ve yöntemin sıkça başvurduğu rol oynama, doğaçlama, rol içinde yazma, kendini yazılı ve sözlü ifade etme becerileri önem kazanmaktadır.

Genel olarak yaratıcılık, bilinen bir şeyden yeni bir şey çıkarmak, özgün bir senteze varmak, bir takım sorunlara yeni çözüm yolları bulmak şeklinde tanımlanır. Ergenlik dönemi içinde bulunan çalışma grubu öğrendiklerinden yeni ve özgün bir senteze varmak için yaratıcı drama yönteminin sıkça başvurduğu doğaçlama, rol oynama, rol içinde yazma tekniklerinden faydalanma imkânı bulacaklardır. Bu da yaratıcılıklarının gelişmesine olanak sağlayacaktır. Bu yöntemle daha önce tanışmayan çalışma grubunun çalışmaya ve ünite konularına merakı artmıştır. Çalışmanın gönüllü yapılması katılımın sürekliliğini sağlamıştır. 


\section{Veri Toplama Aracı}

Veri toplama aracı olarak katılımcılara çalışmadan önce ve sonra İlköğretim Fen ve Teknoloji dersi 7. sınıf ünitesine ait Uzay Bilmecesi ünitesinde hedeflenen kazanımları içeren başarı testi ön test ve son test olarak uygulanmıştır. Uygulanan başarı testinin standart sapması, aritmetik ortalaması, t-test değeri belirlenmiştir. Bunun yanın sıra teste ait mod, ortanca ve ranj değerleri belirlenerek testin geçerlilik ve güvenirliliği ortaya konmuştur. Çalışma süresince her günün sonunda yapılan çalışmaya ait öğretmenin gözlemi adı altında sürece ait notlar alınmıştır. Bunun yanı sıra tüm çalışma süresince öğrencilerden her günün sonunda çalışmaya ait edindikleri bilgi, düşünce ve hissettiklerini içeren günlük tutmaları istenmiştir.

\section{4. İşlem}

Çalışmada kullanılan yöntem yaratıcı dramadır. Çalışma yapılandırılırken yaratıcı drama aşamaları 1- Hazırlık - 1sınma, 2- Canlandırma, 3- Değerlendirme olarak uygulanmıştır (Adıgüzel, 2002). Yaratıcı drama yönteminin sıkça başvurduğu doğaçlama, canlandırma, rol oynama, rol içinde yazma, liderin role girmesi tekniklerinden yararlanılmıştır. Çalışma sonucunu görmek amacıyla ön test-son test kontrol gruplu deneysel bir çalışma yapılmıştır. Yaratıcı drama temelli ders işlemeye uygun çalışma ortamı açısından klasik sınıf yerine okulun anasınıfı tercih edilmiştir. Çalışmaya ait ayrıntılı atölye içeriği Ek-1 de sunulmuştur.

Çalışmaya başlamadan önce üniteye ait yıldız, kuyruklu yıldız, takım yıldızı, güneş, dünya, meteor gök taşı, meteor çukuru, gezegen, gezegenlerin güneşe uzaklıkları, gezegen uydu arasındaki ilişki, gezegenlere ait özellikler (büyüklük, uydu sayısı, halka sayısı, güneşe uzaklık), dünya dışı varlıklar, ünlü Türk astronomi bilginleri, dünyanın uydusu Ay ve Ay’a yapılan yolculuk araştırılmıştır. Elde edilen bilgiler ilköğretim 7. sınıf ünitesindeki konu ve kazanımlara uygun hâle getirilerek yaratıcı drama temelli 10 ders planı hazırlanmıştır. Ders planları hazırlanırken program geliştirme sürecinin öğeleri; amaç ve hedefler, içerik, öğretme öğrenme süreci (yaklaşım, yöntem, teknik, araç ve gereçler vd.), değerlendirme dikkate alınmıştır. Atölye içeriğinin oluşturulmasında Adıgüzel (2002)'in yaratıcı drama aşamalarından, oturum konuları ve yaratıcı drama arasındaki ilişkiyi sağlamada ise çeşitli kaynaklardan (Adı̈üzel, 2005; San 1997, 2003) yararlanılmıştır. Ayrıca öğrenciler arasındaki paylaşımı artırmak, birbirleri hakkında bilgi sahibi olmalarını ve grup içi etkili iletişimi sağlamak amacı ile 2 saatlik grup içi iletişim başlıklı ders planı hazırlanmıştır.

Konuklu İlköğretim Okulunda öğrenim gören 7. sınıf öğrencileri ile çalışmadan önce yaratıcı drama temelli ders işlenmesi konusunda yapılandırılmamış görüşmeler yapılmıştır. Çalışma grubunun ünite konularına ve ilköğretim 7. sınıf öğretim programında yer alan kazanımlara ait bilgilerini öğrenmek amacı ile konuyla ilgili 20 soruluk bir başarı testi hazırlanmış ve uygulanmıştır. Çalışmanın sonunda aynı başarı testi tekrar uygulanmıştır. Ayrıca öğrencilerden çalışma süresince atölye hakkında günlük tutmaları istenmiştir. Çalışmanın sonunda atölyelerden elde edilen anlamlı buldukları çalışmalarını birleştirerek bir astronomi dergisi hazırlamaları ve bu dergiye bir isim bulmaları istenmiştir. 12 atölyenin 1 tanesinde öğrencilerinde izni alınarak farklı bir kişi tarafından kamera çekimi yapılmıştır. Çalışma 1-13 Mart 2011 tarihleri arasında hafta içi her gün saat 10.00 ile 11.00 saatleri arasında birer saatlik 12 oturumdan oluşmaktadır.

\section{Verilerin Analizi ve Bulgular}

\subsection{Uzay Bilmecesi Ön Test ve Son Testten Elde Edilen Verilerin Analizi}

Uygulanan ilköğretim 7. sınıf uzay bilmecesi ünitesine ait kazanımları içeren başarı testinden elde edilen veriler Tablo 1'de sunulmuştur. 
Tablo 1. Başarı Ön Test- Son Testine Ait Ölçümlerinin Değerlendirilmesi (t- testi)

\begin{tabular}{|c|c|c|c|c|c|c|c|}
\hline & $\begin{array}{c}(\mathrm{n}) \\
\text { (kat1lımc1 } \\
\text { say1s1) }\end{array}$ & $\begin{array}{c}(\mathrm{X}) \\
\text { Ortalama }\end{array}$ & $\begin{array}{c}(\mathrm{S}) \\
\text { Standart } \\
\text { Sapma }\end{array}$ & $\begin{array}{c}\text { Sx } \\
\text { Standart } \\
\text { Hata }\end{array}$ & $\begin{array}{c}\% \mathrm{~V} \\
\text { Varyasyon }\end{array}$ & $\mathrm{t}$ & $\begin{array}{c}\text { Önem } \\
\text { denetimi }\end{array}$ \\
\hline Öntest & 14 & 42,29 & 8.90 & 2,38 & 21,05 & \multirow{2}{*}{31,68} & \multirow{2}{*}{$0,000 *$} \\
\hline Sontest & 14 & 93,57 & 6,38 & 1,71 & 6,82 & & \\
\hline Fark & - & 51,29 & 2,52 & 1,62 & 11,82 & & \\
\hline
\end{tabular}

Tablo 1'deki sonuçlar incelendiğinde elde edilen ölçme sonuçları doğrultusunda $t$ test değeri $\mathrm{P}<0,001$ olduğundan yaratıcı drama yöntemi uygulanan grubun ön test ve son test sonuçları arasındaki farkın anlamlı olduğu sonucuna varılabilir. Son testteki başarı artışının büyük olduğu şeklinde yorumlanabilir.

Aritmetik ortalamalara, standart sapmalara ve t değerine bakıldığında projede kullanılan yaratıcı drama yönteminin bu dersin ve bu ünitenin işlenmesinde uygun olacağı çalışmada varılmak istenen hedef kazanımlara hizmet edeceği sonucuna varılmıştır. Ön test ve son teste ait mod, ortanca, ranj değerleri belirlenerek testin geçerlilik ve güvenirliliği ortaya konmuştur. Ön test sonucunda mod 40 iken son testte başarının artmıştır ve sık tekrarlanan değer olan mod değeri 98'e ulaşmıştır. Ön testte ortanca değer 41 iken son teste ortanca değer 96'ya ulaşmıştır. En yüksek not ile en düşük not arasındaki fark olan ranj ise ön testte 38 iken son testte 20 'ye düşerek başarının arttığını göstermiştir.

Tablo 2. Başarı Ön Test- Son Testine Ait mod, ortanca ve ranj Değerleri

\section{Ön test'e ait bilgiler Son test'e ait bilgiler}

\begin{tabular}{lll}
\hline mod & 40 & 98 \\
\hline Ortanca & 41 & 96 \\
\hline Ranj & 38 & 20 \\
\hline
\end{tabular}

\subsection{Gözlemlerden elde edilen verilerin analizi}

Her atölye çalışması sonrası öğrencilerde oluşabilecek duygu, bilgi ve davranış değişimini görmek amacıyla “Öğretmenin Gözlemi” adı altında notlar alınmıştır. Çalışmaya başlamadan önce yaratıcı dramanın aşamaları ile ilgili bir bilgilendirme yapılmıştır. Öğrencilerin oyunlardan oldukça keyif aldıkları, eğlenerek öğrenme konusunda istekli oldukları gözlenmiştir. İlk başlarda verilen yönergeleri takip etmekte zorlandıkları dikkatlerinin verilen yönergeler, yürüyüş ya da düşünceler arasında gidip geldiği fark edilmiştir. İkinci oturumdan itibaren öğrencilerin yönergeleri takip etmekte zorlanmadıkları gözlenmiştir. Kişisel bilgilerin paylaşıldığı hedef kazanımın grup içi iletişimi arttırmak olduğu ikinci oturumda birkaç yıldır aynı okulda, sınıfta olmalarına rağmen ortak birçok özelliklerini yeni keşfettikleri ve paylaşımın arttığı gözlemlendi. Öğrenciler içinde bulundukları gelişim dönemi ve yaşadıkları kültürün etkisi ile ilk başta cinsiyet ayırımında bulunmalarına rağmen oyunların eğlenceli havası ve kazanma duygusuyla bu ayırımı kısa sürede yendikleri fark edilmiştir. İlk başlarda ikili yönergelerde kızlar ve erkekler kendi aralarında ikili oluştururken daha sonraki aşamalarda farklı cinsiyetler bir araya gelmeye başlamıştır. Afişlerle tanıtım aşamasında birbirlerini sözsüz tanımaları, paylaşılan bilgilerin görsel hafıza sayesinde akılda kalmasına yardımcı olmuştur. Üçüncü oturuma başlanmadan önce öğrencilerin yaratıcı drama 
ile ders işleme konusunda oldukça hevesli oldukları ve kendilerini dramacılar olarak adlandırdıkları belirtildi. $\mathrm{Bu}$ oturumun sonunda belli bir iletişim düzeyine geçildiği gözlemlendiğinden üniteye ait bilgilerin paylaşılması sürecine geçildi. Dördüncü oturum gözleminde dikkat çeken nokta öğrencilerin esneme çalışması sırasında bir önceki oturuma ait yıldızları sıcaklıklarına bakarak renklerine göre sınıflandırma yaptıklarıydı. Öğrencilerin yaratıcılıklarını ortaya koyacakları beşinci oturumda güneşin dünya ile ilişkisini anlatan bir şiir yazarak besteledikleri ve hepsinin sürece etkin katıldığı gözlendi. Oturumlar ilerledikçe öğrencilerin özgünlükleri arttı. Yaratıcı dramanın aşamalarına hâkimiyetleri de aynı oranda gerçekleşti. İlk başlarda doğaçlamalarda birbirlerini taklit etmelerine rağmen giderek doğaçlamalara özgünlük hâkim oldu. Meteor ve göktaşı kavramları oldukça karıştırılan kavram kargaşanın yaşanabileceği bir konu olmasına rağmen canlandırmalar sayesinde hiç yanılgıya düşmeden bu iki kavramı ayırt ettiler. Oturumların sonunda gerçekleştirdikleri “.......hissettim,.......öğrendim,........fark ettim” paylaşımları ile süreçten zevk aldıkları, eğlenerek öğrendikleri dile getirildi. Tüm atölyelerin sonunda beğendikleri çalışmaları kullanarak oluşturdukları ve isim verdikleri astroloji dergisi ZUZI 7'nin onları oldukça mutlu ve memnun ettiği gözlemlendi. Uzayda bulunan tüm gök cisimlerinin birbirleri ile uyumlu hareket ettiği ve bu uyumun bozulmasından tüm gök cisimlerinin etkileneceği sonucuna vardıkları gözlemlendi. Öğrencilerin çalışmanın sonundaki paylaşımlarından sürecin bitmesine üzüldükleri ancak oyunla derste anlatılan konuların öğrenilebileceğine sevindikleri fark edildi. Onlar için eğlence aracı olan oyun şimdi bir öğrenme aracıydı. Gözlem sonuçlarına göre çocuğun doğasına uygun bir öğrenme yöntemi uygulandığı düşünülmektedir.

\subsection{Günlüklerden Elde Edilen Verilerin Analizi}

Çalışma süresince öğrencilerden çalışmaya ait düşüncelerini, öğrendiklerini ve duygularını günlüklerine yazmaları istenmiştir. Çalışmanın sonunda toplanan günlüklerde her gün yapılan oturuma ait kazanımları içeren kelimeler tema olarak kullanılmıştır. Temalar kodlanmış ve bu kodlar günlüklerde aranmış, yapılan kodlamalar oranlanarak tabloda sunulmuştur.

Tablo 3. 10. Güne Ait Öğrenci Günlüklerinden Elde Edilen Tema-Kod-Oran Tablosu.

\begin{tabular}{|c|c|c|c|c|c|c|c|c|c|c|c|c|c|c|c|c|}
\hline Tema & Kod & $\mathrm{E}$ & B & S & Y & $\mathrm{H}$ & $\mathrm{C}$ & A & A1 & $\mathrm{F}$ & $\mathrm{L}$ & S1 & S2 & A2 & K & \\
\hline Kuşçu & \multirow{10}{*}{ 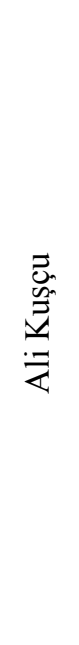 } & $X$ & $\mathrm{X}$ & $\mathrm{X}$ & $\mathrm{X}$ & $\mathrm{X}$ & $\mathrm{X}$ & $\mathrm{X}$ & $\mathrm{X}$ & $\mathrm{X}$ & $X$ & $\mathrm{X}$ & $X$ & $\mathrm{X}$ & $\mathrm{X}$ & 1 \\
\hline Türk & & $\mathrm{X}$ & $\mathrm{X}$ & $\mathrm{X}$ & $\mathrm{X}$ & $\mathrm{X}$ & $\mathrm{X}$ & $\mathrm{X}$ & $\mathrm{X}$ & $\mathrm{X}$ & $\mathrm{X}$ & $\mathrm{X}$ & $\mathrm{X}$ & $\mathrm{X}$ & $\mathrm{X}$ & 1 \\
\hline Astronomi & & $\mathrm{X}$ & $\mathrm{X}$ & $\mathrm{X}$ & $\mathrm{X}$ & $\mathrm{X}$ & $\mathrm{X}$ & $\mathrm{X}$ & $\mathrm{X}$ & $\mathrm{X}$ & $\mathrm{X}$ & $\mathrm{X}$ & $\mathrm{X}$ & $\mathrm{X}$ & $\mathrm{X}$ & 1 \\
\hline Ünlü & & $X$ & $\mathrm{X}$ & $\mathrm{X}$ & $\mathrm{X}$ & $\mathrm{X}$ & $\mathrm{X}$ & $\mathrm{X}$ & & $\mathrm{X}$ & $X$ & $\mathrm{X}$ & $\mathrm{X}$ & $\mathrm{X}$ & $\mathrm{X}$ & $13 / 14$ \\
\hline Bilgin & & $\mathrm{X}$ & $\mathrm{X}$ & $\mathrm{X}$ & & & $\mathrm{X}$ & & & $\mathrm{X}$ & $\mathrm{X}$ & $\mathrm{X}$ & $\mathrm{X}$ & $\mathrm{X}$ & $\mathrm{X}$ & $10 / 14$ \\
\hline Ay & & X & $\mathrm{X}$ & $\mathrm{X}$ & $\mathrm{X}$ & $\mathrm{X}$ & $\mathrm{X}$ & & $\mathrm{X}$ & $\mathrm{X}$ & $\mathrm{X}$ & $\mathrm{X}$ & $\mathrm{X}$ & $\mathrm{X}$ & $\mathrm{X}$ & $13 / 14$ \\
\hline Hareketleri & & $\mathrm{X}$ & $\mathrm{X}$ & $\mathrm{X}$ & $\mathrm{X}$ & $\mathrm{X}$ & $\mathrm{X}$ & & $\mathrm{X}$ & $\mathrm{X}$ & $\mathrm{X}$ & $\mathrm{X}$ & $\mathrm{X}$ & $\mathrm{X}$ & $\mathrm{X}$ & $13 / 14$ \\
\hline Risale & & X & & $\mathrm{X}$ & & & $\mathrm{X}$ & & & & & & $\mathrm{X}$ & $\mathrm{X}$ & & $5 / 14$ \\
\hline Gözlemevi & & X & $\mathrm{X}$ & $\mathrm{X}$ & & $\mathrm{X}$ & $\mathrm{X}$ & $\mathrm{X}$ & $\mathrm{X}$ & $\mathrm{X}$ & $X$ & $\mathrm{X}$ & $X$ & $\mathrm{X}$ & $\mathrm{X}$ & $13 / 14$ \\
\hline Fethiye & & X & X & & & & X & & & & & & X & X & & $5 / 14$ \\
\hline
\end{tabular}




\subsubsection{Afişlerden Elde Edilen Verilerin Analizi}

2. oturum sonunda öğrencilerin belirlenen kazanımlara ne kadar ulaştıklarını görmek amacıyla afişler incelenmiştir. Paylaşılması istenen kişisel özellikleri içeren kelimeler belirlenerek afişlerde aranmıştır. Bu kelimeler kodlanarak kodlar oranlanmıştır. Afişlere ait bilgileri içeren sonuçlar Tablo 4'de sunulmuştur.

\section{Tablo 4. 2. Oturumda Öğrenci kazanımlarını Değerlendirmek İçin Uygulanan Tema-Kod-Oran Tablosu}

\begin{tabular}{|l|c|c|c|c|c|c|c|c|c|c|c|c|c|c|c|}
\hline Temalar & 1 & 2 & 3 & 4 & 5 & 6 & 7 & 8 & 9 & 10 & 11 & 12 & 13 & 14 & Kod \\
\hline F. takımı & & & & & $\mathrm{X}$ & $\mathrm{X}$ & $\mathrm{X}$ & $\mathrm{X}$ & $\mathrm{X}$ & $\mathrm{X}$ & $\mathrm{X}$ & $\mathrm{X}$ & $\mathrm{X}$ & & $9 / 14$ \\
\hline Yemek & & & $\mathrm{X}$ & & & & & $\mathrm{X}$ & & & & & & & $2 / 14$ \\
\hline Meslek & & & $\mathrm{X}$ & & & & & & & & $\mathrm{X}$ & & & & $2 / 14$ \\
\hline Mekân & & $\mathrm{X}$ & $\mathrm{X}$ & $\mathrm{X}$ & $\mathrm{X}$ & $\mathrm{X}$ & $\mathrm{X}$ & & & & & $\mathrm{X}$ & & $\mathrm{X}$ & $8 / 14$ \\
\hline Müzik & $\mathrm{X}$ & & $\mathrm{X}$ & $\mathrm{X}$ & $\mathrm{X}$ & $\mathrm{X}$ & $\mathrm{X}$ & $\mathrm{X}$ & $\mathrm{X}$ & $\mathrm{X}$ & $\mathrm{X}$ & $\mathrm{X}$ & $\mathrm{X}$ & & $12 / 14$ \\
\hline Çiçek & $\mathrm{X}$ & $\mathrm{X}$ & & & & & & & $\mathrm{X}$ & $\mathrm{X}$ & $\mathrm{X}$ & $\mathrm{X}$ & $\mathrm{X}$ & $\mathrm{X}$ & $8 / 14$ \\
\hline Cinsiyet & $\mathrm{X}$ & & $\mathrm{X}$ & $\mathrm{X}$ & $\mathrm{X}$ & $\mathrm{X}$ & $\mathrm{X}$ & $\mathrm{X}$ & & & & & $\mathrm{X}$ & $\mathrm{X}$ & $9 / 14$ \\
\hline Diğer & & $\mathrm{X}$ & & & $\mathrm{X}$ & & $\mathrm{X}$ & & & $\mathrm{X}$ & & $\mathrm{X}$ & & $\mathrm{X}$ & $6 / 14$ \\
\hline
\end{tabular}

\section{Bulgular ve Yorum}

Projenin değerlendirilmesinde ölçme araçlarından elde edilen bulgular aşağıdaki gibidir.

Birinci oturumda kazanımlar; öğrencilerin aralarında göz teması kurması, bedenini etkin kullanması, grup içi etkileşim kurmasıydı. Bu kazanıma ulaşılıp ulaşılmadığını anlamak için oturumun sonunda değerlendirme aşamasında öğrencilerin duygu ve düşünceleri sözlü olarak alınmıştır. Öğrencilere çalışmaya başlarken bu çalışmayla ilgili neler düşündügü ve çalışmanın sonunda düşüncelerinde ne gibi değişiklikler olduğu, oyunlarda ve canlandırma aşamasında neler hissettikleri sorulmuştur. Öğrencilerin büyük çoğunluğunun süreçten oldukça keyif aldıkları dile getirilmiştir. Oyunlarda ve canlandırma aşamasında öğrencilerin birbiriyle göz teması kurdukları gözlenmiştir. Öğrencilerin oynanan sırt sırta köşe kapmaca oyununda ilk seferinde oldukça zorlandıkları, uyumlu hareket edemedikleri, ancak aralarında strateji geliştirdikten sonra uyumlu hareket ettikleri gözlenmiştir. Aslan kedi oyununda öğrencilerin birbirleriyle etkili iletişim kurdukları, hepsinin sürece etkin olarak katıldı̆̆ gözlenmiştir.

İkinci oturumda kazanımlar; öğrencinin kendine ait kişisel özellikleri birbiriyle paylaşmaları, arkadaşını daha yakından tanımasıdır. Bu kazanımlara ulaşmak için yönergeler eşliğinde kişisel bilgilerini paylaşmaları, isimlerinin hikâyelerini birbirlerine anlatmaları istenmiştir. Değerlendirme etkinliklerinde öğrencilerin süreç ile ilgili duygu ve düşüncelerini sözlü olarak paylaşmaları istenmiştir. Öğrenciler birbirlerinin en sevdiği yemekleri öğrendiklerini, arkadaşının dinlediği müzik türünü öğrendiğini dile getirmişlerdir.

K öğrencisi: "S’nin isminin hikâyesini bilmiyordum anlamı çok güzelmiş! Bir kızım olursa adını S koyacağım."

B öğrencisi: L öğrencisi ile aynı takımı tuttuklarını yeni öğrendiğini belirtmiştir.

A1 öğrencisi: E öğrencisi ile aynı tür müzikleri dinlediklerini ve en sevdikleri parçanın aynı olduğunu söylemiştir.

S öğrencisi: Y öğrencisini mutlu etmek için en sevdiği çiçek olan papatyalardan bir demet toplayacağını söylemiştir. 
A öğrencisi: F öğrencisi ile aynı yerleri gezip görmek istediklerini öğrendiğini. Büyüyünce beraber tatile çıkıp merak ettikleri yerleri görmeyi planladıklarını söylemiştir.

Paylaşımların ardından değerlendirme aşamasında öğrencilere kendilerini anlatan birer afiş hazırlatılmıştır. Öğrencilerin afişe bakarak arkadaşını tahmin etmesi istenmiştir. Çalışma 14 öğrenci ile yapılmıştır ve 12 afiş doğru olarak sahibine götürülmüştür. Öğrencilerden bazıları resim yapmaktan hoşlanmadıkları halde kendini resimle anlatmanın değişik ve güzel olduğunu belirtmiştir. Öğrenciler afiş hazırlarken en çok çiçek resimleri kullanılmıştır. En çok gitmek, görmek istedikleri yerlerin deniz kıyısı olduğu görülmüştür. Afişlerde sevdikleri müzik parçalarının nakaratlarını kullanmışlardır. Birçok öğrencinin afişinde cinsiyetini gösteren bir resim vardır. Erkek öğrencilerin afişlerinde sevdikleri, destekledikleri futbol takımlarının ismi ya da amblemi bulunmaktadır.

Afişlerin değerlendirilmesinde içerik analizi kullanılmıştır. Öğrencilerin hazırladıkları afişler incelenmiştir. Öğrencilerin birbirlerine kendilerini tanıtan ve kişiliklerini anlatan kelimeler tema olarak kullanılmıştır. Belirlenen temalar afişlerde aranarak kodlanmış bu kodlar oranlanmıştır. Tablo 2'de bu oranlar sunulmuştur.

Üçüncü oturumda kazanımlar; yıldızların renklerine göre sıcak, soğuk, çok sıcak olarak sınıflandırıldığını ancak yeryüzünden bakıldığında beyaz göründükleri, kuyruklu yıldızın aslında bir yıldız olmadığı, en ünlü kuyruklu ve en son izlenen kuyruklu yıldızı öğrenmesidir. Bu oturumun değerlendirmesinde öğrencilere araştırmacı yazar olarak bir dergiye yıldızlarla ilgili bir yazı yazdırılmıştır. Yazılar incelendiğinde on dört öğrencinin on birinin yıldızlarla ilgili kazanımlardan bahsettiği ve verilen bilgilerin doğru olduğu tespit edilmiştir. Bir öğrencinin yıldızların renklerine göre sınıflandırılması ile ilgili yanlış bilgi verdiği, iki öğrencinin ise kazanımların hepsinden bahsetmediği tespit edilmiştir. Buna göre bu öğrencilerin büyük çoğunluğunun kazanımlara ulaştığ gözlenmiştir.

Dördüncü oturumda kazanımlar; bilinen takımyıldızlarına örnek verme, bildiği takımyıldızlarına yenilerini eklemedir. Değerlendirmede öğrenciler iki gruba ayrılarak içinde takımyıldızı isimlerinin olduğu şifreli bir bulmaca verilmiş ve verilen sürede şifreyi çözmeleri istenmiştir. Her iki takımda bulmacayı çözüp şifreyi bulmuştur ancak bir takım diğerinden daha kısa sürede çözmüştür. Şifre 'yaratıcı darama ile öğrenmek kolay ve çok zevkli’ dir.

Beşinci oturumda kazanımlar; güneşinde bir yıldız olduğu, bu yıldızın Dünya gezegenin 1sı ve 1şık kaynağı olduğu, Dünya gezegeni ile Güneş arasında mesafenin canlının yaşamını etkilediğinin bilinmesidir. Bu oturumun değerlendirmesinde öğrenciler iki gruba ayrılarak Güneş ile ilgili bir şiir yazarak bestelemiştir. Öğrencilerin kazanımlara hizmet edecek birer şiir yazdıkları ve besteledikleri görülmüştür.

Altıncı oturumun kazanımları; meteor ve göktaşının ne olduğu öğrenmesi ve dünyadaki göktaşı çukurları hakkında bilgi sahibi olmasıydı. Bu oturumun değerlendirmesinde öğrencilere rol içinde yazma tekniği ile gazeteye haber yaptırılmıştır. Bu haberin içeriği oluşturulurken oturum sırasında kullanılan fotoğraf kullanılmıştır. Öğrenciler yaptıkları haberde dünyadaki göktaşı çukurundan bahsetmiştir. Ayrıca Ağrı' da göktaşı çukuru olarak bilinen ancak daha sonra da öyle olmadığı anlaşılan çukur ile ilgili haber yaptıkları gözlenmiştir.

Yedinci oturumun kazanımı gezegenleri güneşe uzaklığına göre sıralamaktı. Bu oturumun değerlendirmesi çizimlerle yapılmıştır. On dört öğrencinin on üçünün bu çizimi doğru yaptığı görülmüştür.

Sekizinci oturumun kazanımları; gezegenlerin uydu sayısını öğrenmek, gezegenleri halkalarının varlığına göre sinıflamak, gezegenleri büyüklüklerine göre sıralamaktı. Bu oturumun değerlendirmesinde öğrencilerin tüm bu bilgileri kullanacakları bir tablo verilerek doldurmaları istenmiştir. Bu tablo hazırlanırken MEB ilköğretim yedinci sınıf öğretmen kılavuzundaki önerilen etkinliklerden faydalanılmıştır. On dört öğrencinin yedisi bu tabloları eksiksiz doldurmuştur. Öğrencilerin tümü gezegenleri güneşe uzaklığına göre sıralamıştır. Aynı şekilde tüm öğrenciler halkası bulunan gezegenleri işaretlemiştir. Ancak on dört öğrencinin beşi gezegenlerin uydu sayısını doğru yazamamıştır. On dört öğrencinin on ikisi gezegenlerin bilinen özelliklerini doğru yazmıştır. Dokuz öğrenci gezegenleri büyüklüklerine göre doğru sıralamıştır. Beş öğrenci bu sıralamada en büyük ve en küçük gezegenleri doğru sıralarken aradaki sıralamalarda yanlışlıklar yapmıştır. Sonuç olarak öğrencilerin tümünün 
gezegenleri güneşe uzaklığına göre sıralayabildiği, gezegenlerin halka sayısını bildiği görülmüştür. Öğrencilerin büyük çoğunluğunun gezegenleri büyüklüklerine göre sıralarken ve zorlandığı görülmüştür.

Tablo 5. Öğrencilerin Sekizinci Oturumun Kazanımlarına Ait Doldurdukları Tablonun Doğru-Yanlış Sayısı

\begin{tabular}{|l|l|l|}
\hline & Doğru & Yanlış \\
\hline Güneşe Yakınlık & 14 & - \\
\hline Büyüklük & 9 & 5 \\
\hline Uydu Sayısı & 9 & 3 \\
\hline Halka Sayısı & 14 & - \\
\hline Bilinen Özelliği & 12 & 2 \\
\hline
\end{tabular}

Dokuzuncu oturumun kazanımları; bir önceki oturumdaki öğrendiklerini kullanmak ve dünya dışı varlıklarla ilgili fikir yürütmekti. Bu oturumun değerlendirmesinde dünya dışı varlıkların fiziksel görünümü ile ilgili resim yaptırılmış ve bu varlıklarla ilgili duygu ve düşüncelerini günlüğüne kaydetmeleri istenmiştir.

Onuncu oturumun kazanımı ünlü bir Türk gök bilimci olan Ali Kuşçu’yu tanımak ve onun bilime katkılarını öğrenmekti. Bu oturumun değerlendirmesinde öğrencilerden Ali Kuşçuya mektup yazmaları istenmiştir. Mektupların değerlendirmesinde öğrencilerin Ali Kuşçu'nun bir Türk astronomi bilgini olduğunu, bilime katkılarını öğrendikleri, hayatı hakkında bilgi sahibi oldukları anlaşılmıştır.

Mektuplardan alıntılar:

Öğrenci S: Sevgili Ali, baban iyi ki Uluğ Bey’in kuşçusu olmuş ve sana bu soyadını vermiş sen gökyüzüyle ilgileniyordun ve soyadın Kuşçu baban sanki senin gökyüzüyle ilgileneceğini biliyordu.

Öğrenci A1: Sevgili Ali sen çok iyi bir matematikçiymişsin ben matematik dersini hiç sevmiyorum. Sevseydim belki ben de gökyüzü ile ilgilenirdim. Ben daha çok futbol oynamayı seviyorum futbolcu olacağım. Çok büyük bir takımda oynamak istiyorum.

Öğrenci H: Bugün derste Uluğ Bey’in oğlunun babasını öldürdüğünü öğrendik. Ben babamı çok seviyorum. İnsan babasını nasıl öldürür? Sen de Uluğ Bey’i çok seviyormuşsun baban gibiymiş. Çok üzülmüşsündür.

Öğrenci B: Sen baban gibi sevdiğin birinden habersiz başka bir yere gitmişsin dönüşünde seni affetsin diye bir şeyler getirmişsin sanırım getirdiğin şey önemliymiş ki Uluğ Bey seni affetmiş.

Öğrenci A2: Sen gözlem evinde çalışmışsın çok şeyler başarmışsın ben de gözlem evinde çalışmak isterim. Bu işler zor mu bana yazacağın mektubunda anlat.

Öğrenci S: Sen barış elçisi olmuşsun şimdilerde genelde sanatçılar barış elçisi oluyor. Dünyaya barış yaymak çok güzel.

Öğrenci C: Bugün derste senin 1474 de İstanbul'da öldüğünü öğrendim, bu mektubu okuyamayacaksın ama sen çok iyi ve başarılı olmuşsun. Bugün seninle ilgili çok şey öğrendik. Biz yaratıcı drama yapıyoruz senin hayatını canlandırdık. Bütün arkadaşlarım seni tanıyor. Resmini gördük bugün.

Öğrencilerin mektuplarda daha çok Ali Kuşçu'nun hayatını anlattıkları, risale kavramına hiç değinmedikleri görülmüştür. Ayrıca Ali Kuşçu'dan sonra gök biliminde gerçekleşen çalışmalardan bahsetmedikleri ortaya çıkmıştır.

On birinci oturumun kazanımları; Dünyanın uydusu olan Ay ve Ay’a yapılan yolculuk hakkında bilgi sahibi 
olmaktı. Yapılan yolculuk öncesi, sonrası ve yolculuk anı olmak üzere üç kısma ayrıldı. Öğrencilere Ay’a yapılan yolculuk ile ilgili canlandırmalar yaptırılmıştır. Bu oturumun değerlendirmesinde öğrencilere rol içinde yazma tekniğini kullanılarak Neil Armstrong olarak Ay’a yapılan yolculuğun ardından o gün yaşadıkları ile ilgili günlük yazdırılmıştır.

Öğrencilerin günlüklerinden alıntılar:

Öğrenci Y: Bugün her zamankinden ve herkesinkinden farklı bir yolculuk yaptım.

Öğrenci E: Bugün arkadaşlarımla Ay’ a yolculuk yaptım ben herkesten önce indim ve Ay’a ilk ayak basan ben oldum.

Öğrenci F: Sevgili günlük bu gün dünyanın dışına çıtım. Yani uzaya gittim.

Öğrenci L: Yaptığım yolculuk sayesinde kimse benim adımı unutamayacak adımı tarihe yazdım.

Öğrenci K: Bugün ben ve ekibim çok zor bir işi başardık.

Öğrenci S1: Bu sabah çok erken uyandık Ay’a gittik orda 22 saat kaldık. Dönüşte nerdeyse Büyük okyanusa düşüyorduk. Ama kurtulduk dönüşte herkes bizi alkışladı ve çok zor bir işi başardığımızı söyledi.

On ikinci oturumun kazanımları; Uzay ve evren arasındaki ilişkiyi kurmak, uzaydaki gök cisimlerinin birbiriyle uyumlu hareket ettiklerini öğrenmekti. Bu oturumun değerlendirmesinde öğrencilere birçok harf verilerek öğrendikleri gökcisimlerinin isimlerini oluşturmalarını söylendi öğrenciler dört gruba ayrılmıştı ve bu gruplardan birincisi yirmi altı anlamlı kelimeden yirmisini, ikinci grup on yedisini, üçüncü on beşini, dördüncü grup ise on ikisini verilen sürede oluşturdu. Aynı oturumda öğrencilere öğrendikleri kavramları kullanarak bir kavram haritası hazırlamaları söylenmiştir. Tüm öğrenciler ortak çalışmışlar ve 12 kavram kullanılarak bir kavram haritası oluşturmuşlardır.

Tüm çalışmalardan elde edilen resim, yazı, bulmaca, tablo ve bilgiler kullanılarak bir astroloji dergisi hazırlanmıştır ve bu dergiye Zuzi7 adı verilmiştir.

\section{Sonuç ve Öneriler}

Yapılan çalışmada elde edilen veriler analiz edildiğinde ve oturumdan elde edilen bulgulara bakıldığında Fen ve Teknoloji Dersi İlköğretim 7. Sınıf Öğretim Programı'nda belirlenen (Ek-4) hedef kazanımlara ulaşmada kullanılan yöntemin uygun olduğu ve yapılan çalışmanın hedeflenen başarıya ulaştığı görülmektedir.

Bu proje, 13-15 yaş arası ilköğretim yedinci sınıf on dört öğrenci ile yedinci sınıf öğretim programında bulunan uzay bilmecesi ünitesinin işlenmesinde yaratıcı dramanın katkısını belirlemek amacıyla tasarlanmış ve uygulanmıştır. Bu çalışma ön test- son test tek grup deneysel uygulamalı bir çalışmadır. Çalışmadan elde edilen bulgular doğrultusunda projenin belirlenen hedeflere ulaştığı saptanmıştır. İlköğretim beş ve yedinci sinıfta “Güneş Sistemi-Gezegenler" ünitesinin işlenmesinde sınıf öğretmenlerine, fen ve teknoloji öğretmenlerine yardımcı olabilecek bir çalışmadır. Yaratıcı drama, ilköğretim çağındaki öğrencilerin doğasına uygun olarak oyunsu süreçlerle bilgi edinilmesine olanak sağlayan bir yöntemdir. Ayrıca yaratıcı drama öğretmen ve eğitimcilerin, çocukların ve ergenlerin dünyayı algılayabilmeleri yönünde, kendileri ve sosyal çevre ile iletişime girmede yararlanabilecek bir alandır (San,1991 s.584). Yaratıcı drama, öğrenme ve öğretme sürecinde, bildik "aktif-pasif öğrenici“" etkileşimi yerine süreçteki tüm öğrencileri "aktif öğreniciye" dönüştürmektedir. Bu yüzden diğer yöntemlere göre öğrencinin daha çok ilgisini çekmektedir. Yaratıcı dramanın aşamalarından biri olan canlandırmada gerçekleştirilen doğaçlama ve rol oynama sayesinde öğrenci daha önce karşılaşmadığı belki de karşılaşamayacağı durumların içine girerek neler yaşanabileceğini, yapabileceğini deneyimler. Bu da yaşantılar yoluyla öğrenmeyi sağlayarak öğrencinin öğrenme sürecine katkıda bulunur. Böylece yaparak yaşayarak öğrenme gerçekleşmiş olur. Başka bir değişle, yaratıcı drama çalışmalarıyla öğrencinin öğrenmeyi öğrendiği söylenebilir. 
Bu projede çalışılan on dört kişilik grup, yaratıcı drama geçmişi olmayan ancak daha önce aynı sınıf ortamını paylaşan bir grup olmasına rağmen projenin ilk iki oturumunda öğrencilerin sürece rahat adapte olmalarını sağlamak amacıyla iletişim etkileşim çalışmalarına yer verilmiştir. Bunun çalışmaya olumlu katkı sağladığg düşünülmektedir. Mekân açısından sorun olmadıkça daha fazla kişi ile çalışılabileceği öngörülmektedir. Ancak sayı arttıkça öğrencilerin sürece birebir katılımının sağlanmasına dikkat edilmelidir. Bu çalışmada daha fazla görsel öğe kullanılarak kazanımlar daha etkin hale getirilebilir. Çalışmanın başlangıcında grupta öğrenciler arasında -yaşadıkları kültürün etkisi ile- cinsiyet ayırımına ilişkin çeşitli davranışlar gözlemlenmesine rağmen bu ayırımın büyük ölçüde aşıldığ 1 söylenebilir. Yapılan hazırlık 1sınma çalışmalarındaki oyunlar sayesinde öğrencilerin farkında olmadan bu engeli ortadan kaldırdığı gözlenmiştir. Yapılacak olan benzer çalışmalarda grup içi iletişim etkileşim kazanımlı oturum sayısı attırılabilir. İleride yapılacak olan proje çalışmalarında aynı çalışmaya kontrol grubu eklenerek yapılacak yeni bir uygulama, yaratıcı drama yöntemi ile başka bir yöntemi karşılaştırmaya firsatı verecektir.

\section{Kaynakça}

Adıgüzel, Ö. H. (2005). Süreçsel Drama, Tiyatro Sporu ve Drama'da Zaman. Ankara: Naturel Yayınları

Adıgüzel, Ö. H. (2002). Eğitim bilimlerinde ve sanat eğitiminde yöntem, disiplin ve sanatsal bayutlarıyla yaratıcı drama. 11. Eğitim Bilimleri Kongresi. Yakın Doğu Üniversitesi, KKTC, 23-26 Ekim.

Akdeniz, A. R., Yıldız, İ. ve Yiğit, N. (2001). İlköğretim 6. Sınıf Öğrencilerinin Işık Ünitesindeki Kavram Yanılgıları, Eğitim Fakültesi Dergisi, 2, 20, 72-77.

Albayrak, A., ve Akdemir, B. (2002). Fen Eğitiminde Yeni Yaklaşımlar, V. Ulusal Fen Bilimleri ve Matematik Eğitimi Kongresi, Özetler, Ankara, 335.

Aral, N., Bulut, Ş., Baran, G. ve Çimen, S. (1981). Eğitimde Drama. İstanbul: YA-PA Yayın.

Arı, R., Üre, Ö., Yılmaz, H. (1998). Gelişim ve Öğrenme Psikolojisi. Konya: Mikro Yayıncılık.

Büyükkasap, E., Düzgün, B., Ertuğrul, M. ve Samancı O. (1998). Bilgisayar Destekli Fen Öğretiminin Kavram Yanılgıları Üzerine Etkisi, Kastamonu Eğitim Dergisi, 6, 59-66.

Boydak H. A. (2004). Öğrenci Merkezli Etkinlikler Neden Gereklidir?, Bilim ve Aklın Aydınlığında Eğitim Dergisi, yıl 5, $52-53$.

Erhan, T. Ü. (2000). İlköğretimde Hayat Bilgisi Dersinin Drama ile Verilmesinin Dersin öğrenilmesine ve Çocukların Benlik Kavramlarına Etkisinin İncelenmesi, Yayımlanmamış Yüksek Lisans Tezi, Hacettepe Üniversitesi, Ankara.

Gümüş, S., Öner, F., Kara, M., Orbay, M. ve Yaman, S. (2005). Isı ve Sıcaklık Üzerine Kavram Yanılgıları, http://yayim. meb.gov.tr/dergiler/157/icindekiler.htm.

Güneş, B. (2005). Fizikteki Kavram Yanılgıları, http://www. w3.gazi.edu.tr/web/bgunes/ - 58k.

Hardal, Ö. ve Eryılmaz, A. (2002) Basit Araçlarla Yaparak Öğrenme Metoduna Göre Geliştirilen Elektrik Devreleri ile İlgili Aktivitelerin Öğrencilerin Fizik Başarılarına ve Tutumlarına Etkileri, V. Ulusal Fen Bilimleri ve Matematik Eğitimi Kongresi, Özetler, Ankara, 117.

İşman, A., Baytekin, Ç., Balkan, F., Horzum, M.B. ve Kıyıcı, M. (2005). Fen Bilgisi Eğitimi ve

Yapısalcı Yaklaşım, http://www.tojet.net/articles/117.htm, 20 Haziran 2005.

Kamen, M. (1992). Creative Drama and the Enhancement of Elementary School Students' Understanding of Science Concepts, Dissertation Abstracts International, DAI-A, 52/07, 2489.

Kurt, Ş. (2002). Bütünleştirici Öğrenme Kuramı’na Uygun Çalışma Yapraklarının Geliştirilmesi, Yüksek Lisans Tezi, Karadeniz Teknik Üniversitesi, Fen Bilimleri Enstitüsü, Trabzon.

Labow, B. J. ve Sewell, R. (1993). CommandPerformances, ScienceandChildren, 31, 2,23-24.

Mcdermott, L. C. (2003). Improving Student Learning in Science, Physical Science News United Kingdoom, University of Liverpool, 4, 2, 6-10 
Özmen, H., Demircioğlu, G. ve Ayas, A. (2001). Bazı Kimya Kavramlarıyla İlgili Öğrenci Yanılgıları: Bir Literatür Araştırması, Fen Bilimleri Eğitimi Sempozyumu, Maltepe Üniversitesi Bildiriler Kitabı, İstanbul, 414-420.

Pantidos, P. Spathi, K. Vitoratos, E. (2001). The Use of Drama in Science Education: The Case of Blegdamsvej Faust. Science and Education.

http://www.ingentaconnect.com/content/klu/sced/2001/00000010/F0020001/00203114;jsessionid=8msrdpsmtbs0e.henrietta (29.01.2009)

Sağırlı, H. (2001). İlköğretim 6. Sınıf Fen Bilgisi Dersinde Dramatizasyon Yönteminin Başarıya Etkisi, Yüksek Lisans Tezi, Marmara Üniversitesi, İstanbul.

San, İ. (Editör) (1997). 7. Uluslar arası Eğitimde Yaratıcı Drama Semineri. Ankara: Naturel Yayıncılık

San, İ.(Editör) (2002). Egitimde Yaratıcı Drama, Yaratıcı Drama,1985-1995, Yazılar, 1.cilt. Naturel, Ankara,

San, İ. (Editör) (2003). Drama ve Öğretim Bilgisi. 5. Uluslararası Eğitimde Yaratıcı Drama Semineri. Atölye ve Konferans Etkinlikleri, (2. Baskı). Ankara: Naturel Yayınc1lık

Tanrıseven, I. (2000). Matematik Öğretiminde Problem Çözme Stratejisi Olarak Dramatizasyonun Kullanılması, Yüksek Lisans Tezi, Marmara Üniversitesi, İstanbul.

Tezci, E. ve Gürol, A. (2005). Oluşturmacı Öğretim Tasarımı ve Yaratıcılık. http://tojet.net/articles/218.htm, 30 Nisan 2005.

URL-2, http://www.istekyasam.com/edu7dergi/edu7/makale3.doc Fen Öğretiminde Bilgisayardan Yararlanma: Uygulama Örnekleri. 24 Eylül 2005.

Uzuntiryaki, E., Çakır, Ö. ve Geban, Ö. (2001). Kavram Haritaları ve Kavramsal Değişim Metinlerinin Öğrencilerin Asit Bazlar Konusundaki Kavram Yanılgılarının Giderilmesine Etkisi, Fen Bilimleri Eğitimi Sempozyumu, Maltepe Üniversitesi Bildiriler Kitab1, İstanbul, 281-284.

Üstündağ, T. (1997). The Advantages of Using Drama As a Method of Education in Elementary Schools, Hacettepe Üniversitesi Eğitim Fakültesi Dergisi, 13, 89-94.

Yürük, N. ve Çakır, Ö. S. (2000). Lise Öğrencilerinin Oksijenli ve Oksijensiz Solunum Konusunda Görülen Kavram Yanılgılarının Saptanması, Hacettepe Üniversitesi Eğitim Fakültesi Dergisi, 18, 185-191. 


\section{EKLER}

Ek-1 Örnek Oturum Planı

Ders: Fen ve Teknoloji

Konu: Gezegenler 1

Süre: 1 saat

Mekân: Konuklu İlköğretim Okulu Anasınıfı A Şubesi

Grup: 6 kız, 8 erkek 14 öğrenci

Yöntem: Yaratıcı Drama

Teknikler: Rol oynama, doğaçlama

Araç/ Gereç: Kalem, boya kalemleri, A4 kâğıt, gezegenlere ait bilgi kartları

\section{Kazanımlar:}

- Gezegenleri Güneşe uzaklığına göre sıralar.

\section{Süreç:}

\section{Hazırlık / Isınma}

Etkinlik 1: Öğretmen öğrencilere çember olmalarını söyler. Çemberde toplanan öğrenciler i 1, 2 diye sırayla saydırarak iki gruba ayırır. Öğrenciler tek sıraya girerler. Öğretmen önceden kâğıtlara yazdığı gezegen isimlerini ilk öğrenciye( güneşe uzaklığına göre sıraya dizilmiş) gösterir. Öğrenciler birbirlerinin kulağına söyleyerek son öğrenciye kadar iletir. Son öğrenci gezegenin adını kâğıda yazar. Hangi grup ilk önce bitirirse oyunu kazanır. $\mathrm{Bu}$ arada yazılan gezegen isimlerinin doğru olması gerekir doğru yazılmayan cevaplar kabul edilmez.

Etkinlik 2: Öğretmen öğrencileri 1, 2, 3, 4 diye saydırarak aynı rakamdaki öğrencileri bir grup oluşturacak şekilde dört farklı gruba ayırır. Gruplara bütün gezegen isimlerini kâğıtlara yazdırır. Öğrencilerden ilk hecelerini kesmelerini ister. Daha sonra ilk heceden ilk harfi kesmelerini söyler. Kesilen heceleri ve ilk harfleri kullanarak bir tekerleme yazmalarını ve bu tekerlemeleri hareketlerle kuvvetlendirmelerini söyler. Öğrenciler hazır olduklarında tekerlemelerini söyler. En çok beğenilen, en akılda kalıcı tekerleme birinci seçilir.

\section{Canlandırma}

Etkinlik 1: Öğretmen öğrencilere bir hikâye anlatır.

\section{Güneşin Korku Dolu Anları}

O gün tüm gezegenler, yıldızlar, kuyrukluyıldızlar, takımyıldızları meteorlar kısacası tüm gök cisimleri güneşin düzenlediği yemeğe davetlilerdi. Güneşin evi oldukça uzaktaydı. Davetliler güneşin evine gitmek için birkaç ışık yılı yol kat ettiler. Herkes oradaydı. Çünkü güneş bugün gezegenleri kendine yakınlığına göre sıraya dizecekti. Yapılan yoklamada en küçük gezegen olan Merkür'ün olmadığı anlaşıldı. Bunun üzerine tüm gök cisimleri harekete geçti her yerde küçük Merkür gezegenini aradılar. En sonunda Merkür gezegenini başka galaksideki gezegen arkadaşlarıyla saklambaç oynarken buldular. Bu durum karşısında çok endişelenen Güneş:

“'Bundan sonra bana en yakın gezegen MERKÜR sen olacaksın! Böylece seni kontrol etmem daha kolay olacak."

İkinci sıra ise güneşin sevgilisi güzeller güzeli VENÜS'E verilecek.

Üçüncü sıraya Venüs'ün ikizi DÜNYA getirilecek. 
Dördüncü sıra Dünya gezegenin en çok ilgilendiği MARS' a verilecek.

Beşinci sıraya gezegenlerin en büyüğ̈̈ JÜPİTER getirilecek.

Altınc1 surada bilinen 56 tane uydusu olan SATÜRN yer alacak.

Yedinci sıraya bir varil gibi yuvarlanan URANÜS yerleştirilecek.

Sekizinci yani son sirada ise NEPTÜN yer alacak.

Ancak bu sıralamaya gezegenlerin itirazları vardı. Şimdi sizden hikâyenin bundan sonrasını canlandırmanızı istiyorum.

Etkinlik 2: Öğretmen öğrencileri çemberde toplar öğrencilere Yeni, Gezegene, Gitmek, Lazım diye sayd1rır. Öğrencileri dört gruba ayırır. Gezegenlere ait özelliklerin bulunduğu kâğıtları sınıfa asar. Tüm gruplara şu yönergeyi verir: Y11 2110 uzay teknolojisi çok gelişti. Artık insanlar tatillerini başka gezegenleri ziyaret ederek geçiriyorlar. Sizde ailenizle gideceğiniz bir gezi programı hazırlıyorsunuz. Amerika, Hawaii, İstanbul derken aklınıza başka bir fikir geldi. En iyisi yeni bir gezegene gitmek diye düşündünüz. Ancak hangi gezegene gideceğiniz ile ilgili kafanızda soru işaretleri var. Gideceğiniz bu gezegeni neye göre seçeceksiniz yönergesini vererek canlandırmalarını söyler. Hazırlıklarını tamamlayan grup canlandırmayı yapar.

\section{Değerlendirme}

Etkinlik 1: Öğretmen öğrencileri dört gruba ayırarak gezegenleri Güneşe uzaklıklarına göre sıraya dizen bir resim çizmelerini söyler. Çizilen resimleri incelemelerini ister. Isınma/hazırlık çalışmalarında birinci seçilen tekerlemeyi çizdikleri resimlerin altına yazmalarını söyler.

\section{Ek-2 Ön Test Son Test Soruları}

\section{Ön Test Uygulaması}

\section{Sorular}

1. Güneş, Dünya ve Ay’ı büyüklüklerine göre nasıl sıralayabiliriz?

2. Dünya ve Ay nasıl hareket etmektedir?

3. Gökyüzündeki yıldızlardan hangilerinin isimlerini biliyorsunuz?

4. Bildiğiniz takımyıldızlarının adlarını yazın.

5. Sizce yıldızlar ne renktir?

6. En ünlü kuyruklu yıldızın adı nedir?

7. Türkiye'de göktaşı çukuru var diye bilinen ancak sonradan göktaşı çukuru olmadığı anlaşılan ilimiz hangisidir.

8. Dünya üzerindeki en büyük göktaşı çukurunun nerede olduğunu yazın.

9. Gezegenlerin bildiğiniz genel özelliklerini yazın.

10. Gezegenimiz Dünyanın komşuları hangi gezegenlerdir?

11. Gezegenlerin Güneşe yakınlıklarına göre sıralamasını yazınız.

12. Gezegenimiz Dünyada yaşayan canlılar başka gezegenlerde yaşayabilir mi? Neden?

13. Dünya dışındaki evren parçasına ne ad verilir?

14. En son gözlenen kuyruklu yıldızın ismi nedir?

15. Güneşin etrafında en kısa sürede dolaşan gezegen hangisidir?

16. Uzay araştırmaları ile ilgili son duyduğunuz haberi paylaşır mısınız?

17. Uzay mı büyüktür, yoksa Evren mi? 
18. AY 'a atılan ilk adımlar ile ilgili ne biliyorsunuz?

19. Güneş saati yapan, İstanbul'un enlem ve boylam derecelerini belirleyen. Astronomi Risalesi'ni yazan ünlü Türk gök bilimci kimdir?

20. Güneşsiz bir Dünyayı hiç düşündünüz mü? Güneş olmazsa Dünyada neler değişir?

Not: Sınav süresi40 dk'dır

Her soru 5 puandir.

Bilginizi paylaştığınız için teşekkür ederim.

Ek-3 Uzay Bilmecesi

\begin{tabular}{|l|l|l|l|l|l|l|l|l|l|l|l|l|l|l|l|}
\hline K & U & Z & E & Y & T & A & C & I & B & A & L & I & N & A & K \\
\hline Y & A & S & R & A & T & G & Ü & N & E & Y & T & A & C & I & O \\
\hline İ & K & İ & Z & L & E & R & I & S & A & A & T & B & C & I & L \\
\hline D & R & N & A & E & J & D & E & R & H & A & M & U & A & I & T \\
\hline L & Y & E & N & G & E & C & E & A & V & C & I & Y & A & Y & U \\
\hline A & Ö & K & A & G & R & O & G & L & A & K & E & U & N & M & K \\
\hline G & E & K & L & K & O & B & A & L & I & K & L & K & K & K & Ç \\
\hline O & M & A & S & A & A & A & A & Y & K & O & V & A & U & U & A \\
\hline B & A & S & A & K & P & N & V & E & C & C & O & Y & R & G & L \\
\hline K & N & T & A & Y & U & Y & E & L & K & E & N & I & T & U & G \\
\hline Z & K & $\ddot{~ U ~}$ & Ç & U & K & A & Y & I & E & Y & U & N & U & S & I \\
\hline V & A & K & T & E & R & A & Z & I & K & A & R & T & A & L & L \\
\hline C & E & N & N & E & T & K & U & S & U & I & T & U & R & N & A \\
\hline
\end{tabular}

10 Harf: CENNETKUȘU 5 Harf: YUNUS

TURNA

9 Harf: KUZEYTACI

GÜNEYTACI

ÇALGI

ÇOBAN

SINEK

8 Harf: BÜYÜKAYI

BALIK

KÜÇÜKAYI

ASLAN

OĞLAK

7 Harf: İKIZLLER

EJDERHA

4Harf: SAAT

AVCI

MASA

KOVA

6 Harf: BALINA KUPA

YENGEÇ

KUĞU

YELKEN

KOLTUK

TERAZİ

3Harf: KOÇ

KARTAL

TAY

YAY

Şifre: YARATICI DRAMA İLE ÖĞRENMEK KOLAY VE ÇOK ZEVKLİ. 
Ek-4 Oturum Kazanım Tablosu

\begin{tabular}{|c|c|}
\hline 1.OTURUM & $\begin{array}{ll}\text { - } & \text { Grup üyeleri ile göz teması kurar. } \\
\text { - } & \text { Bedenini etkin kullanır. } \\
\text { - } & \text { Grup içi etkili iletişim kurar. }\end{array}$ \\
\hline 2.OTURUM & $\begin{array}{ll}\text { - } & \text { Kendine ait bilgileri arkadaşıyla paylaşır. } \\
\text { - } & \text { Arkadaşının daha önce bilmediği özelliklerini öğrenir. }\end{array}$ \\
\hline 3.OTURUM & $\begin{array}{l}\text { - Yıldızların sıcaklıklarına göre sarı, kırmızı ve mavi olarak sınıflandırıldığını, yeryü- } \\
\text { zünden bakıldığında beyaz göründüğünü öğrenir. } \\
\text { - } \quad \text { Kuyruklu yıldızlar hakkında bilgi sahibi olur. } \\
\text { - } \quad \text { Kuyruklu yıldızlara örnek verir. }\end{array}$ \\
\hline 4.OTURUM & $\begin{array}{l}\text { - } \quad \text { Bilinen takımyıldızlara örnekler verir. } \\
\text { - } \quad \text { Bildiği takımyıldızlara yenilerini ekler. }\end{array}$ \\
\hline 5.OTURUM & $\begin{array}{ll}\text { - } & \text { Güneşin de bir yıldız olduğunu öğrenir. } \\
\text { • } & \text { Güneşin Dünya gezegenin ısı ve ışık kaynağı olduğunu öğrenir. } \\
\text { • } & \text { Güneş ile Dünya arasındaki uzaklığın canlının yaşamını etkilediğini fark eder. }\end{array}$ \\
\hline 6.OTURUM & $\begin{array}{ll}\text { - } & \text { Meteorun ne olduğunu öğrenir. } \\
\text { - } & \text { Göktaşının ne olduğunu öğrenir. } \\
\text { - } & \text { Dünyadaki meteor çukurları hakkında bilgi sahibi olur. }\end{array}$ \\
\hline 7.OTURUM & - Gezegenleri Güneşe uzaklığına göre sıralar \\
\hline 8.OTURUM & $\begin{array}{ll}\text { - } & \text { Gezegenlerin uydu sayısını öğrenir. } \\
\text { - } & \text { Gezegenleri halkalarının varlığına göre sınıflar. } \\
\text { - } & \text { Gezegenleri büyüklüklerine göre sıralar. }\end{array}$ \\
\hline 9.OTORUM & $\begin{array}{l}\text { - } \quad \text { Gezegenlere ait (uydu sayısı, rengi, güneşe uzaklıkları) özellikleri öğrenir. } \\
\text { - } \quad \text { Dünya dışı varlıklar hakkında fikir yürütür. }\end{array}$ \\
\hline 10.OTURUM & $\begin{array}{ll}\text { - } & \text { Ali Kuşçunun bir ünlü Türk astronomi bilgini olduğunu öğrenir. } \\
\text { - } & \text { Ali kuşçunun hayatı hakkında bilgi sahibi olur. } \\
\text { - } & \text { Ali kuşçunun bilime katkılarını öğrenir. }\end{array}$ \\
\hline 11.OTURUM & $\begin{array}{l}\text { - } \quad \text { Ay hakkında bilgi sahibi olur. } \\
\text { - } \quad \text { Ay'a yapılan yolculuk hakkında bilgi sahibi olur. }\end{array}$ \\
\hline 12.OTURUM & $\begin{array}{l}\text { - } \quad \text { Uzay ve evren arasındaki ilişkiyi kurar. } \\
\text { - } \quad \text { Uzay’daki bütün gök cisimlerinin uyum içinde hareket ettiklerini öğrenir. } \\
\text { - } \quad \text { Edindiği bilgileri tekrar eder. }\end{array}$ \\
\hline
\end{tabular}




\section{Summary}

\section{Unit of the 7th Grade Elementary School Science Lesson "Space Enigma" to be dealt with Creative Drama Method}

\author{
Berna SAVAŞÇI ${ }^{3}$
}

\author{
Pınar ÖZDEMIR ŞİMŞEK ${ }^{4}$
}

\section{Introduction}

In 21 st century is new age for human kind demands him to become familiar with his environment, to adopt new situations, to develop new points of views for the problems he may face. Education helps people to develop themselves, to change and to adopt new situations. The need to adopt new situations urges the education system to change, too. Now, it is time to train students as the ones who wonder, research, have different performances and develop new projects. Life-long learning has crucial importance. Furthermore, an effective learning and teaching process of science can be achieved through a meaningful and permanent learning and teaching process (Yürük ve Çakır, 2000). Science and technology course requires understanding, interpreting what is understood, and the concept using formulas and concepts correlating. Thus, it is one of the lessons in which both students have difficulty in learning and teachers have difficulty in teaching process. Therefore, as knowledge becomes their own through the creation of a first person, creative drama is a good alternative.

\section{The Significance of the Study}

Students have difficulty in developing experiences related to the topics they learn in science and technology course in their daily life. Since there are mainly abstract concepts in this course they may face confusion and fail to learn these concepts. In this paper, it is foreseen that these abstract concepts can be concretized and conceptualized through creative drama. It is assumed that most commonly used creative drama techniques such as role play, improvisation, leading into the role, writing in the role can help us to achieve these goals implied above.

\section{The Purpose of the Study}

The purpose of the study is to achieve the goals of the unit:"Space Enigma"in the 7th grade curriculum which covers properties and inter-compatibility of the space bodies (stars, comets, constellations, meteors, planets, the sun) using the creative drama method to help 7th grade students to have experiences and make a clear sense of these bodies. And also it aims to help students have self-esteem know the planet they live on and the galaxy in which this plant is situated.

\section{Method}

The method applied in this study include both qualitative and quantitative methods. In quantitative part, a science achievement test was applied as pre and post test. As a research design, it is a one group experimental study. The determination of the sample was based on voluntariness. Nursery classroom of the school is chosen as the place to provide a more comfortable place to promote students' participation.

3 Teacher, Ministry Education, bernasavasci@mynet.com.tr

4 Assistant Professor Hacettepe University, pozdem@hacettepe.edu.tr 


\section{Sample}

The sample of this study consists of 6 girls and 8 boys at total 14 students who are attending to 7/A classroom at Konuklu Elementary School in the spring term of the 2010-2011 academic year, do not have a creative drama background.

\section{Instruments}

From March 1 to13 an hour a day at total 12 hours of workshops has been carried out. One of the 12 lesson plans prepared is presented as an example. To have a clear idea of the process and the results pre-tests and posttests about "Space Enigma" have been applied, teachers' observations are taken into consideration and students have been asked to keep dairies during the process.

\section{Procedure}

Before the study, a detailed literature review about the unit: "Space Enigma" in the 7th grade curriculum which covers properties and inter-compatibility of the space bodies (stars, comets, constellations, meteors, planets, and the sun) was conducted. In the light of this literature review 10 lesson plans about this unit were prepared based on creative drama. Furthermore, to promote group communication among students, to share and to know each other 2 lesson plans were prepared. All of these plans were applied from March 1 to 13 and during this process students were asked to keep dairies.

\section{Findings and Discussions}

\section{The analysis of the findings of pre-test and post-test of Space Enigma}

The results of the pre test and post test are show in Table 1.

\section{The analysis of the findings obtained from observations}

There are 12 observation made by teachers.

\section{The analysis of the findings obtained from Dairies}

The subjects assumed form the dairies are encoded and these subjects are calculated and shown in the table.

\section{Results and Suggestions}

In this study, we tried to achieve the goals of the unit:"Space Enigma"in the 7th grade curriculum which covers properties and inter-compatibility of the space bodies (stars, comets, constellations, meteors, planets, the sun) using the creative drama method. This study was carried out with 6 girls and 8 boys at total 14 students who are attending to 7/A classroom at Konuklu Elementary School in the spring term of the 2010-2011 academic year, do not have a creative drama background. According to the findings, it can be stated that the purpose of the study achieved since the students were able to achieve the goals of this unit. 